\title{
Influence of Different Sources of Organic Manures and Decomposers on Enzymatic Activity and Microbial Dynamics of Rhizosphere Soil of Chilli (Capsicum annum L.)
}

\author{
Karale Gangadhar $^{1 *}$, N. Devakumar ${ }^{1}$, Vishwajith ${ }^{1}$ and G. Lavanya $^{2}$ \\ ${ }^{1}$ Department of Agronomy, ${ }^{2}$ Department of Agricultural Microbiology, University of \\ Agricultural Sciences, GKVK, Bengaluru-65, India \\ *Corresponding author
}

A B S T R A C T

\section{Keywords}

Organic sources, jeevamrutha, decomposers, micro bial population, organic chilli

\section{Article Info}

Accepted:

15 December 2019 Available Online: 20January 2020
A field experiment was conducted at research and demonstration block of Research Institute on Organic Farming (RIOF), UAS, GKVK, Bengaluru during 2017-2018 to study the combined effect of different sources of organic manures, decomposers on enzymatic activity and microbial dynamics of rhizosphere soil of chilli. The experiment was laid out on Factorial Randomized Block Design with 12treatments and replicated thrice. Irrespective of decomposers treatments, application of vermicompost on $\mathrm{N}$ equivalent basis had recorded significantly higher chilli yield (20.47 and $\left.23.09 \mathrm{t} \mathrm{ha}^{-1}\right)$ and stalk yield (5.28 and $6.15 \mathrm{t} \mathrm{ha}^{-1}$ ) as compared to the application of poultry manure (19.40 and $21.85 \mathrm{t}$ $\mathrm{ha}^{-1}, 5.01$ and $\left.5.83 \mathrm{t} \mathrm{ha}^{-1}\right)$, sheep manure (18.83 and $21.19 \mathrm{t} \mathrm{ha}^{-1}, 4.86$ and $\left.5.65 \mathrm{tha}^{-1}\right)$ and FYM (18.27 and $20.54 \mathrm{t} \mathrm{ha}^{-1}, 4.74$ and $\left.5.50 \mathrm{t} \mathrm{ha}^{-1}\right)$.Application of jeevamrutha to soil had recorded significantly higher chilli yield (18.27 and $\left.20.54 \mathrm{t} \mathrm{ha}^{-1}\right)$ and stalk yield (4.74 and $\left.5.50 \mathrm{t} \mathrm{ha}^{-1}\right)$ as compared to application of microbial consortia (20.17 and $22.74 \mathrm{t} \mathrm{ha}^{-1}, 5.21$ and $\left.6.07 \mathrm{t} \mathrm{ha}^{-1}\right)$ and NCOF-decomposer (16.24 and $18.20 \mathrm{t} \mathrm{ha}^{-1}, 4.2$ and $4.88 \mathrm{t} \mathrm{ha}^{-}$ $\left.{ }^{1}\right)$.Application of vermicompost had recorded significantly higher bacterial population $\left(27.15 \times 10^{5}\right.$ and $30.29 \times 10^{5} \mathrm{CFU} \mathrm{g}^{-1}$ of soil, respectively) as compared to FYM $(24.23 \times$ $10^{5}$ and $26.87 \times 10^{5} \mathrm{CFU} \mathrm{g}{ }^{-1}$ of soil), poultry manure $\left(25.73 \times 10^{5}\right.$ and $28.63 \times 10^{5} \mathrm{CFU} \mathrm{g}^{-1}$ of soil)and sheep manures $\left(24.97 \times 10^{5}\right.$ and $27.74 \times 10^{5} \mathrm{CFU} \mathrm{g}{ }^{-1}$ of soil).Application of jeevamrutha recorded significantly higher bacterial population $\left(28.27 \times 10^{5}\right.$ and $31.59 \times$ $10^{5} \mathrm{CFU} \mathrm{g}^{-1}$ of soil, respectively) as compared to NCOF- decomposer (21.54 and $23.73 \times$ $10^{5} \mathrm{CFU} \mathrm{\textrm {g } ^ { - 1 }}$ of soil, respectively). Interaction effects of these factors didn't differ significantly.

\section{Introduction}

Chilli (Capsicum annuum L.) is a popular vegetable crop,commonly known as bell pepper or sweet pepper or hot pepper or chilli. Chilli is grown over an area of 19.89 million hectares in the World, with a production of 33.52 million tonnes (Patel, 2017). Major 
chilli growing countries are India, China, Indonesia, Korea, Pakistan, Turkey and Sri Lanka in Asia. India is the world leader in chilli production followed by China and Pakistan. In India, green chilli is grown in an area of 3.66 lakh hectares with anuual production of 35.92 lakh tones and productivity of 10.2 million tones during 2018(Anon.,2018). This shows that the bulk share of chilli production is in Asian countries, though it is produced throughout the world. In India, chillies are grown in almost all the state throughout the country. Andhra Pradesh is the largest producer of chilli in India and contributes about 26 per cent to the total area followed by Maharashtra (15\%), Karnataka (11\%), Orissa (11\%),Madhya Pradesh (7\%) and other states contributing nearly $22 \%$ to the total area under Chilli. The lion's share is taken by India with $36 \%$ share in global production, followed by China (11\%), Bangladesh (8\%), Peru (8\%) and Pakistan (6\%)(Anon., 2018).

The quality of compost can be improved by using different microbial inoculants. The wastes can be co-inoculated with decomposing lingo-cellulolytic microbes and enriching free living $\mathrm{N}_{2}$ fixers, phosphate solubilizers and Plant Growth Promoting Rhizobacteria (PGPRs). PGPRs are the microorganisms which help in promotion/ protection of plant by their association with plants. PGPRs are colonizing the root surface to survive, multiply and compete with another micro biota (Kloepper, 1994).Some examples of PGPR are like Agrobacterium, Bacillus, Chromobacterium, Erwinia, Flavobacterium, Pseudomonas andTrichoderma

(Bhattacharyya and Jha, 2012).

All organic manures are decomposed organic matter obtained by the action of microbial population in a warm and moist aerobic environment using cow dung, cow urine and other waste materials available from backyard cattle (Ramprasad et al., 2009). Usage of decomposers such as jeevamrutha, microbial consortia and NCOF- decomposer results in increased growth and yield of crops and improve the soil physico-chemical and biological properties. They contain micro and macro nutrients, many vitamins, essential amino acids, beneficial microorganisms and growth promoting substances viz., IAA, GA (Devakumar et al., 2008 and Tharmaraj et al., 2011). Jeevamrutha are eco-friendly organic preparations made from cow products. The products from cow have the ability to bring the flow of cosmic energy which in turn can revitalize the growth process (Natarajan, 2002). Use of farm yard manure (FYM) and liquid organic formulations like panchagavya and jeevamrutha are potential sources of organic nutrients. Hence, the present investigation was conducted to study the combined effect of vermicompost, FYM, poultry manure, sheep manure and jeevamrutha on growth, yield, enzymatic activity and microbial dynamics of chilli.

\section{Materials and Methods}

A field experiment was conducted at research and demonstration block of Research Institute on Organic Farming, University of Agricultural Sciences, Gandhi Krishi Vignana Kendra, Bengaluru which is situated in Eastern dry zone of Karnataka at a latitude of $12^{\circ} 58^{\prime}$ North, longitude of $75^{\circ} 35^{\prime}$ East and at an altitude of $930 \mathrm{~m}$ above mean sea level. The experiment was conducted to study the combined effect of different sources of organic manure, jeevamrutha and decomposers on growth and yield of chilli during kharif - 2017 and 2018 under irrigated condition. The experiment was laid out on factorial Randomized Block Design with 12 treatments replicated thrice. The treatment are $\mathrm{T}_{1}$ :FYM x Jeevamrutha, $\mathrm{T}_{2}$ : FYM x Microbial consortia, $\mathrm{T}_{3}$ : FYM $\mathrm{x}$ Decomposer, $\mathrm{T}_{4}$ :Vermicompost $\mathrm{x} \quad$ Jeevamrutha, 
$\mathrm{T}_{5}$ :Vermicompost $\mathrm{x}$ Microbial consortia, $\mathrm{T}_{6}$ :Vermicompost $\mathrm{x}$ Decomposer, $\mathrm{T}_{7}$ : Poultry manure $\mathrm{x}$ Jeevamrutha, $\mathrm{T}_{8}$ : Poultry manure $\mathrm{x}$ Microbial consortia, $\mathrm{T}_{9}$ : Poultry manure $\mathrm{x}$ Decomposer, $\mathrm{T}_{10}$ : Sheep manure $\mathrm{x}$ Jeevamrutha, $\mathrm{T}_{11}$ : Sheep manure $\mathrm{x}$ Microbial consortia and $\mathrm{T}_{12}$ :Sheep manure $\mathrm{x}$ Decomposer. Recommended dose of nutrients for chilli is $150: 75: 75 \mathrm{~N}: \mathrm{P}_{2} \mathrm{O}_{5}: \mathrm{K}_{2} \mathrm{O} \mathrm{kg} \mathrm{ha}{ }^{-1}$ and nutrients were supplied through FYM, vermicompost, poultry manures and sheep manures on the basis of nitrogen equivalent. Treatment combinations consisted of four different organic sources $\left(\mathrm{M}_{1}\right.$ : FYM, $\mathrm{M}_{2}$ : Vermicompost, $\mathbf{M}_{3}$ : Poultry Manure and $\mathbf{M}_{4}$ : Sheep manures-100 \% N equivalent basis), three decomposers (J: Jeevamrutha, $\mathrm{C}$ :Microbial consortia and $\mathrm{N}$ : decomposer developed by NCOF). Different sources of organic manure were incorporated into the soil, three weeks prior to planting. Application of jeevamrutha at $2000 \mathrm{l} \mathrm{ha}{ }^{-1}$, microbial consortia and NCOF- decomposer were applied at the time of planting and at different growth stages. Soil of the experimental site was red sandy loam with a $\mathrm{pH}$ of 6.93 , EC $\left(0.27 \mathrm{dSm}^{-1}\right)$, low in organic carbon $(0.44 \%)$ and medium in available nitrogen $\left(292 \mathrm{~kg} \mathrm{ha}^{-}\right.$ $\left.{ }^{1}\right), \mathrm{P}_{2} \mathrm{O}_{5}\left(27 \mathrm{~kg} \mathrm{ha}^{-1}\right)$ and $\mathrm{K}_{2} \mathrm{O}\left(241 \mathrm{~kg} \mathrm{ha}^{-1}\right)$. Experimental data collected was subjected to statistical analysis by adopting Fisher's method of analysis of variance (ANOVA) as outlined in Gomez and Gomez (1984). Critical difference (CD) values were calculated whenever the " $F$ " test was significant at 5 per cent level.

\section{Results and Discussion}

Effect of different sources of organic manures and decomposers on yield of chilli

Green chilli yield varied significantly due to application of different sources i.e., FYM, vermicompost, poultry manure and sheep manure during Kharif, 2017 and 2018 seasons.
Significantly higher green chilli yield (20.47 and $23.09 \mathrm{t} \mathrm{ha}^{-1}$ ) was recorded with the application of vermicompost it was 10.74 and 11.04 per cent higher yield over the application of FYM. Whereas, the application of vermicompost recorded 5.23 and 5.37 per cent higher yield over application of poultry manure (Table 1). Among the decomposers, significantly higher green chilli yield (21.31 and $24.06 \mathrm{t} \mathrm{ha}^{-1}$ ) was recorded with the application of jeevamrutha at $2000 \mathrm{l} \mathrm{ha}^{-1}$ as compared to microbial consortia (20.17 and $22.74 \mathrm{t} \mathrm{ha}^{-1}$ ) and decomposer (16.24 and $18.20 \mathrm{t} \mathrm{ha}^{-1}$ ) and it was 23.79 and 24.35 per cent increase in yield with application of jeevamrutha during both the seasons (Table $1)$. These results are in conformity with the findings of Vishwajith et al., (2018) in okra, ReshmaSutar et al., (2018) in cowpea, Naveena (2017) in ragi, RekhaGonal (2017) in baby corn, BasavarajKumbar et al., (2017) in french bean. The increase in yield might be due to significant increase in yield parameters such as higher number of fruits, fruit length and fruit weight. These results are in line with Somasundaram (2003) in maize-sunflowergreengram system, Boomiraj (2003) in bhendi and Yadav and Lourduraj (2006) in rice.

Increase in yield parameters might be due to higher total dry matter accumulation (TDMA). Higher TDMA might be due to higher plant height which resulted in more number of branches and more leaf area. Significantly higher dry matter production was recorded with the application of jeevamrutha throughout the crop growth period possibly due to the continuous supply of nutrients and plant growth promoting substances available in jeevamrutha. This is in conformity with Sreenivasa et al., (2009) and Nileema Gore and Sreenivasa (2011) who have also reported higher plant height, root length, dry matter production, number of fruits per plant and fruit weight of tomato with the application of jeevamrutha. Lower chilli yield (16.24 and 
$18.20 \mathrm{t} \mathrm{ha}^{-1}$ ) was recorded during kharif, 2017 and kharif, 2018 with decomposer application (Table 1). The possible reasons might be due to higher nutrient content and beneficial microbes such as bacterial, fungi, N- fixers, Psolubilizers and actinomycetes present in jeevamrutha might have resulted in higher growth and yield of crop. The increased yield was also might be due to sink potential as indicated due to better availability of nutrients and moisture, which helped in production of more photosynthates and its translocation to fruits during their peak stage of crop growth. This might have fulfilled the crop nutrient demand and enhanced yield (Sreenivasa et al., 2009). Application of organic matter to the soil improves the rhizosphere properties to a greater extent. This would favour the growth and multiplication of soil flora and fauna (Devakumar et al., 2014). The organic manures have the capacity to fulfill the nutrient demand of the crops adequately and promote the activity of beneficial micro and macro flora in the soil (Mohan Singh, 2003). This might have helped in greater availability of nutrients in the rhizosphere soil and enhanced the uptake of nitrogen, total phosphorus and total potassium during 2017 and 2018, respectively. Presence of higher amount of organic substances in the rhizosphere soil possibly provided favourable environment and substrate availability to the beneficial soil microorganisms. Similar results were also observed by Mohammad and Farzaneh (2019) reported that higher nutrient uptake of total nitrogen, phosphorus and potassium was observed in mungbean crop with the application of vermicompost $10 \mathrm{t} \mathrm{ha}^{-1}$ as compared to FYM and control.

\section{Interaction effect ofdifferent sources of organic manures and decomposer on growth and yield of chilli}

Interaction effect among different sources of organic manure and decomposers was found to be observed. Numerically higher and lower fruit yield (22.30 and $14.85 \mathrm{t} \mathrm{ha}^{-1}$ ) and stalk yield (5.75 and $3.87 \mathrm{t} \mathrm{ha}^{-1}$ ) were observed in the treatment combined application of vermicompost and jeevamrutha and FYM and decomposers respectively.

From this study it can be concluded that application of different organic manures (FYM, vermicompost, poultry manure and sheep manure) and decomposers (jeevamrutha microbial consortia and decomposer) are beneficial in improving growth and yield of chilli by providing better availability of nutrients, improved microbial activity and availability of growth promoting substances.

Effect of different organic manures, jeevamrutha and decomposers on soil microbial population

The increase in microbial population is a key indicator of soil fertility and soil health. Microbial communities are important for the functioning of the ecosystem, both in relation to direct interactions with plants and with regard to nutrient and organic matter cycling. They are involved in the fundamental activities that ensure the stability and productivity of both agricultural systems and natural ecosystems. Increase in population results in increased soil microbial biomass, a temporary reservoir of labile nutrients. Further, increase in various other biological activities such as enzyme activities, mineralization capabilities, rate of nitrification, microbial diversity etc., will have influence on soil fertility. These biological parameters can also be used as effective indicators for assessing long-term soil and crop management effects on soil quality.

Application of vermicompost and jeevamrutha have significantly influenced the bacteria, fungi, actinomycetes and $\mathrm{P}$ - solubilizer population in the soil at all stages of crop 
growth. In the present investigation, application of vermicompost through $\mathrm{N}$ equivalent recorded significantly higher bacteria (27.15 and $30.29 \times 10^{5} \mathrm{CFU} \mathrm{g}^{-1}$ soil), actinomycetes $\left(23.36\right.$ and $25.71 \times 10^{3} \mathrm{CFU} \mathrm{g}^{-1}$ soil) and fungi (16.94 and $19.61 \times 10^{4} \mathrm{CFU} \mathrm{g}^{-1}$ soil) and P- solubilizer (32.43 and $34.53 \times 10^{5}$ CFU $\mathrm{g}^{-1}$ soil) population during both the seasons and it was followed by application of poultry manure through $\mathrm{N}$ equivalent and lower population was with FYM application (Table 2 and 3). This might be due to the decomposition of organic matter. The work of breaking down of organic material is done is done by bacteria and fungi of many kinds and takes place in the several stages, various intermediate products being formed before the final substance nitrate. These results are in the line with KulvinderKaur et al., (2005), Boraiah et al., (2017) and Siddappa, (2015). Further, these microorganisms solubilize the nutrients and made available for the uptake of nutrients. These results are in conformity with Lavanya et al., (2016) and they opined that maximum population of general bacteria, fungi, actinomycetes, Pseudomonas and PSB were observed in the soil treated with jeevamrutha at $10001 \mathrm{ha}^{-1}$ and 7.5 per cent panchagavya in field bean when compared to without jeevamrutha and panchagavya treated soil. This might be due to the fact that jeevamrutha serves as a good source of beneficial microorganisms and it is in conformity with the findings of Devakumae et al., (2014) Kiran (2014) in chickpea, Siddappa (2015) in fieldbean and Madhukumar (2015) in chilli who have also reported the higher beneficial microbial population and the beneficial effect of jeevamrutha in enhancing the microbial load in the rhizosphere region. Further, Devakumar et al., (2008) have also reported that maximum microbial population was observed between $9^{\text {th }}$ and $12^{\text {th }}$ day after preparation of jeevamrutha. This might have enhanced the decomposition process in the soil which might have resulted in relatively quick release of nutrients from compost than without the application of jeevamrutha.

Application of jeevamrutha at $20001 \mathrm{ha}^{-1}$ recorded significantly higher microbial population in soil viz., bacteria (28.27 and $31.59 \times 10^{5} \mathrm{CFU} \mathrm{g} \mathrm{g}^{-1}$ soil), actinomycetes (24.32 and $26.82 \times 10^{3} \mathrm{CFU} \mathrm{g}^{-1}$ soil), fungi (17.63 and $20.46 \times 10^{4} \mathrm{CFU} \mathrm{g}^{-1}$ soil) and PSB (33.76 and $34.83 \times 10^{5} \mathrm{CFU} \mathrm{g}^{-1}$ soil during both the seasons, respectively) as compared to application of microbial consortia and NCOFdecomposer (2 and 3). This might be due to enhanced effect of jeevamrutha on soil micro flora as compared to individual applications and also jeevamrutha and panchagavya had supported the multiplication of different beneficial microbes. These results are in consonance with the findings of Lavanya et al., (2016), ReshmaSutar et al., (2017) and Boraiah et al., (2017). Similarly, jeevamrutha and panchagavya contains enormous amount of microbial load which multiplies in the soil and acts as a tonic to enhance the microbial activity in the soil (Devakumar et al., 2008 and Patel et al., 2014). According to Devakumar et al., (2014), use of handful of soil for jeevamrutha preparation serves as source of initial inoculum of bacteria, fungi, actinomycetes, $\mathrm{N}$ - fixers and $\mathrm{P}$ - solubilizers.

Hence, more number of beneficial microorganisms were found in organic liquid manure formulations. This might have helped in increasing the microorganisms with the application of jeevamrutha.

Among the different treatment combinations, application of vermicompost and jeevamrutha at $2000 \mathrm{l} \mathrm{ha} \mathrm{ha}^{-1}$ recorded higher microbial population viz., bacteria (29.58 and $33.12 \times$ $10^{5} \mathrm{CFU} \mathrm{g}^{-1}$ of soil), actinomycetes (25.45 and $28.12 \times 10^{3} \mathrm{CFU} \mathrm{g}^{-1}$ of soil), fungi (18.45 and $21.45 \times 10^{4} \mathrm{CFU} \mathrm{g}^{-1}$ of soil) and PSB (35.33 and $37.43 \times 10^{5} \mathrm{CFU} \mathrm{g}^{-1}$ of soil) as compared to individual application. This might be due to 
the beneficial effect of organic material which serves as a source of carbon and energy for soil microorganisms in addition to the liquid manures which contains enormous amount of microbial load which multiplies in the soil and acts as a tonic to enhance the microbial activity in the soil (KulvinderKaur et al., 2005, Siddappa et al., 2017, Latha et al., 2016 and Boraiah et al., 2017).

Table.1 Green chilli yield and stalk yield of chilli as influenced by application of organic manures, jeevamrutha and decomposers during kharif 2017 and 2018

\begin{tabular}{|c|c|c|c|c|c|c|c|c|}
\hline \multirow[t]{4}{*}{ Manures } & \multicolumn{8}{|c|}{ Green chilli yield $\left(\mathrm{t} \mathrm{ha}^{-1}\right)$} \\
\hline & \multicolumn{4}{|c|}{2017} & \multicolumn{4}{|c|}{2018} \\
\hline & \multicolumn{4}{|c|}{ Decomposers } & \multicolumn{4}{|c|}{ Decomposers } \\
\hline & $\mathbf{J}$ & C & $\mathbf{N}$ & Mean & $\mathbf{J}$ & C & $\mathbf{N}$ & Mean \\
\hline FYM & 20.66 & 19.30 & 14.85 & 18.27 & 23.30 & 21.73 & 16.59 & 20.54 \\
\hline VC & 22.30 & 20.61 & 18.51 & 20.47 & 25.20 & 23.24 & 20.81 & 23.09 \\
\hline PM & 21.38 & 20.59 & 16.22 & 19.40 & 24.14 & 23.23 & 18.17 & 21.85 \\
\hline SM & 20.90 & 20.19 & 15.39 & 18.83 & 23.59 & 22.76 & 17.21 & 21.19 \\
\hline \multirow[t]{2}{*}{ Mean } & 21.31 & 20.17 & 16.24 & & 24.06 & 22.74 & 18.20 & \\
\hline & \multicolumn{2}{|c|}{ S.Em \pm} & \multicolumn{2}{|c|}{$\mathrm{CD}(\mathrm{P}=\mathbf{0 . 0 5})$} & \multicolumn{2}{|c|}{ S.Em \pm} & \multicolumn{2}{|c|}{$\mathrm{CD}(\mathrm{P}=\mathbf{0 . 0 5})$} \\
\hline M & \multicolumn{2}{|c|}{0.510} & \multicolumn{2}{|c|}{1.496} & \multicolumn{2}{|c|}{0.596} & \multicolumn{2}{|c|}{1.749} \\
\hline D & \multicolumn{2}{|c|}{0.442} & \multicolumn{2}{|c|}{1.295} & \multicolumn{2}{|c|}{0.516} & \multicolumn{2}{|c|}{1.514} \\
\hline M x D & & & & & & & & \\
\hline \multirow[t]{4}{*}{ Manures } & \multicolumn{4}{|c|}{0.885} & I t ha & & & \\
\hline & \multirow{2}{*}{\multicolumn{4}{|c|}{2017}} & \multicolumn{4}{|c|}{2018} \\
\hline & \multicolumn{3}{|c|}{ posers } & & \multicolumn{4}{|c|}{ Decomposers } \\
\hline & $\mathbf{J}$ & C & $\mathbf{N}$ & Mean & $\mathbf{J}$ & C & $\mathbf{N}$ & Mean \\
\hline FYM & 5.34 & 4.99 & 3.87 & 4.74 & 6.22 & 5.81 & 4.48 & 5.50 \\
\hline VC & 5.75 & 5.32 & 4.78 & 5.28 & 6.71 & 6.20 & 5.56 & 6.15 \\
\hline PM & 5.52 & 5.31 & 4.20 & 5.01 & 6.43 & 6.19 & 4.86 & 5.83 \\
\hline SM & 5.39 & 5.21 & 3.98 & 4.86 & 6.29 & 6.07 & 4.61 & 5.65 \\
\hline \multirow[t]{2}{*}{ Mean } & 5.50 & 5.21 & 4.21 & & 6.41 & 6.07 & 4.88 & \\
\hline & \multicolumn{2}{|c|}{ S.Em \pm} & \multicolumn{2}{|c|}{$\mathrm{CD}(\mathrm{P}=\mathbf{0 . 0 5})$} & \multicolumn{2}{|c|}{ S.Em \pm} & \multicolumn{2}{|c|}{$\mathrm{CD}(\mathrm{P}=0.05)$} \\
\hline M & \multicolumn{2}{|c|}{0.132} & \multicolumn{2}{|c|}{0.386} & & & & \\
\hline D & & & & & & & & \\
\hline M x D & & & & & & & & \\
\hline
\end{tabular}

CD at $5 \%$ NS - Non-significant DAT- Days after Transplanting RDF: $125: 75: 63 \mathrm{~kg} \mathrm{~N}: \mathrm{P}_{2} \mathrm{O}_{5}: \mathrm{K}_{2} \mathrm{O} \mathrm{ha}^{-1}$ for $\mathrm{N}$ equivalent $\mathrm{FYM}$ application FYM - Farm yard manure VC - Vermicompost $\quad$ PM - Poultry manure J - Jeevamrutha
M - Manures

D - Decomposers SM - Sheep manure $\mathbf{N}$ - Decomposer from NCOF 
Table.2 Soil microbial population of chilli at harvest of as influenced by application of organic manures, jeevamrutha and decomposers during kharif 2017

\begin{tabular}{|c|c|c|c|c|c|c|c|c|}
\hline \multirow[t]{4}{*}{ Manures } & \multicolumn{8}{|c|}{ Microbial population } \\
\hline & \multirow{2}{*}{\multicolumn{4}{|c|}{$\begin{array}{c}\text { Bacteria } \\
\left(\text { No. } \times \mathbf{1 0}^{5} \mathrm{CFU}^{-1} \text { of soil }\right) \\
\text { Decomposers }\end{array}$}} & \multirow{2}{*}{\multicolumn{4}{|c|}{$\begin{array}{c}\text { Actinomycetes } \\
\left(\text { No. } \times \mathbf{1 0}^{3} \mathrm{CFU}^{-1} \text { of soil }\right) \\
\text { Decomposers }\end{array}$}} \\
\hline & & & & & & & & \\
\hline & $\mathbf{J}$ & $\mathbf{C}$ & $\mathbf{N}$ & Mean & $\mathbf{J}$ & C & $\mathbf{N}$ & Mean \\
\hline FYM & 27.40 & 25.60 & 19.70 & 24.23 & 23.58 & 22.03 & 16.95 & 20.85 \\
\hline VC & 29.58 & 27.33 & 24.55 & 27.15 & 25.45 & 23.52 & 21.12 & 23.36 \\
\hline PM & 28.36 & 27.32 & 21.52 & 25.73 & 24.40 & 23.50 & 18.51 & 22.14 \\
\hline SM & 27.73 & 26.78 & 20.41 & 24.97 & 23.86 & 23.04 & 17.56 & 21.49 \\
\hline \multirow[t]{2}{*}{ Mean } & 28.27 & 26.76 & 21.54 & & 24.32 & 23.02 & 18.53 & \\
\hline & \multicolumn{2}{|c|}{ S.Em \pm} & \multicolumn{2}{|c|}{$\mathrm{CD}(\mathrm{P}=\mathbf{0 . 0 5})$} & \multicolumn{2}{|c|}{ S.Em \pm} & \multicolumn{2}{|c|}{$\mathrm{CD}(\mathrm{P}=\mathbf{0 . 0 5})$} \\
\hline $\mathbf{M}$ & \multicolumn{2}{|c|}{0.676} & \multicolumn{2}{|c|}{1.984} & \multicolumn{2}{|c|}{0.582} & \multicolumn{2}{|c|}{1.707} \\
\hline D & \multicolumn{2}{|c|}{0.586} & \multicolumn{2}{|c|}{1.718} & \multicolumn{2}{|c|}{0.504} & \multicolumn{2}{|c|}{1.478} \\
\hline M x D & \multicolumn{2}{|c|}{1.172} & \multicolumn{2}{|c|}{ NS } & \multicolumn{2}{|c|}{1.008} & \multicolumn{2}{|c|}{ NS } \\
\hline \multirow[t]{4}{*}{ Manures } & \multicolumn{8}{|c|}{ Microbial population } \\
\hline & \multicolumn{4}{|c|}{ Fungi (No. $\times 10^{4} \mathrm{CFU} \mathrm{g}^{-1}$ of soil) } & \multicolumn{4}{|c|}{ PSB $\left(\right.$ No. $\times 10^{5}$ CFU $\mathrm{g}^{-1}$ of soil) } \\
\hline & \multicolumn{4}{|c|}{ Decomposers } & \multicolumn{4}{|c|}{ Decomposers } \\
\hline & $\mathbf{J}$ & $\mathbf{C}$ & $\mathbf{N}$ & Mean & $\mathbf{J}$ & $\mathbf{C}$ & $\mathbf{N}$ & Mean \\
\hline FYM & 17.09 & 15.97 & 12.28 & 15.11 & 32.73 & 30.58 & 23.52 & 28.94 \\
\hline VC & 18.45 & 17.05 & 15.31 & 16.94 & 35.33 & 32.65 & 29.32 & 32.43 \\
\hline PM & 17.69 & 17.04 & 13.42 & 16.05 & 33.88 & 32.63 & 25.70 & 30.73 \\
\hline $\mathbf{S M}$ & 17.29 & 16.70 & 12.73 & 15.58 & 33.12 & 31.99 & 24.38 & 29.83 \\
\hline \multirow[t]{2}{*}{ Mean } & 17.63 & 16.69 & 13.44 & & 33.76 & 31.96 & 25.73 & \\
\hline & \multicolumn{2}{|c|}{ S.Em \pm} & \multicolumn{2}{|c|}{$\mathrm{CD}(\mathrm{P}=\mathbf{0 . 0 5})$} & \multicolumn{2}{|c|}{ S.Em \pm} & CD (I & $=0.05)$ \\
\hline $\mathbf{M}$ & & & & & & & & \\
\hline D & & & & & & & & \\
\hline M x D & & & & & & & & \\
\hline $\begin{array}{l}\text { at } 5 \% \quad \mathbf{N} \\
\mathbf{F}: 125: 75: 63 \\
\text { M - Farm yarc } \\
\text { - Sheep man }\end{array}$ & $\begin{array}{l}\text { Non-Sig } \\
\mathrm{N}_{2} \mathrm{P}_{2} \mathrm{O}_{5} \text { : } \\
\text { lanure }\end{array}$ & ficant & $\begin{array}{l}\text { DAT- Day } \\
\text { N equiva } \\
\text { C - Vern } \\
\text { - Jeevan }\end{array}$ & $\begin{array}{l}\text { After Tra } \\
\text { t FYM a } \\
\text { ompost } \\
\text { tha }\end{array}$ & $\begin{array}{l}\text { ting } \\
\text { tion }\end{array}$ & $\begin{array}{l}\text { M - N } \\
\text { D - D } \\
\text { PM - } \\
\text { C - M }\end{array}$ & $\begin{array}{l}\text { ures } \\
\text { omposers } \\
\text { ultry man } \\
\text { obial Con }\end{array}$ & \\
\hline
\end{tabular}

$\mathbf{N}$ - Decomposer from NCOF 
Table.3 Soil microbial population of chili at harvest as influenced by application of organic manures, jeevamrutha and decomposers during kharif 2018

\begin{tabular}{|c|c|c|c|c|c|c|c|c|}
\hline \multirow[t]{4}{*}{ Manures } & \multicolumn{8}{|c|}{ Microbial population } \\
\hline & \multirow{2}{*}{\multicolumn{4}{|c|}{$\begin{array}{c}\text { Bacteria } \\
\left(\text { No. } \times \mathbf{1 0}^{\mathbf{5}} \mathrm{CFU}^{-1} \text { of soil }\right) \\
\text { Decomposers }\end{array}$}} & \multicolumn{4}{|c|}{$\begin{array}{l}\text { Actinomycetes } \\
\times 10^{3} \mathrm{CFU} \mathrm{g}^{-1} \text { of soil) }\end{array}$} \\
\hline & & & & & \multicolumn{4}{|c|}{ Decomposers } \\
\hline & $\mathbf{J}$ & C & $\mathbf{N}$ & Mean & $\mathbf{J}$ & $\mathbf{C}$ & $\mathbf{N}$ & Mean \\
\hline FYM & 30.58 & 28.47 & 21.58 & 26.87 & 25.96 & 24.17 & 18.32 & 22.82 \\
\hline VC & 33.12 & 30.50 & 27.24 & 30.29 & 28.12 & 25.89 & 23.13 & 25.71 \\
\hline PM & 31.70 & 30.48 & 23.70 & 28.63 & 26.91 & 25.88 & 20.12 & 24.30 \\
\hline SM & 30.96 & 29.85 & 22.41 & 27.74 & 26.28 & 25.35 & 19.03 & 23.55 \\
\hline \multirow[t]{2}{*}{ Mean } & 31.59 & 29.82 & 23.73 & & 26.82 & 25.32 & 20.15 & \\
\hline & \multicolumn{2}{|c|}{ S.Em \pm} & \multicolumn{2}{|c|}{$\mathrm{CD}(\mathrm{P}=\mathbf{0 . 0 5})$} & \multicolumn{2}{|c|}{ S.Em \pm} & \multicolumn{2}{|c|}{$\mathrm{CD}(P=0.05)$} \\
\hline $\mathbf{M}$ & \multicolumn{2}{|c|}{0.781} & \multicolumn{2}{|c|}{2.291} & \multicolumn{2}{|c|}{0.663} & \multicolumn{2}{|c|}{1.945} \\
\hline D & \multicolumn{2}{|c|}{0.676} & \multicolumn{2}{|c|}{1.984} & \multicolumn{2}{|c|}{0.574} & \multicolumn{2}{|c|}{1.684} \\
\hline$M \times D$ & \multicolumn{2}{|c|}{1.353} & \multicolumn{2}{|c|}{ NS } & \multicolumn{2}{|c|}{1.149} & \multicolumn{2}{|c|}{ NS } \\
\hline \multirow[t]{4}{*}{ Manures } & \multicolumn{8}{|c|}{ Microbial population } \\
\hline & \multicolumn{4}{|c|}{ Fungi (No. $\times 10^{4} \mathrm{CFU} \mathrm{g}^{-1}$ of soil) } & \multirow{2}{*}{\multicolumn{4}{|c|}{$\begin{array}{c}\text { PSB (No. } \times 10^{5} \text { CFU } \mathrm{g}^{-1} \text { of soil) } \\
\text { Decomposers }\end{array}$}} \\
\hline & \multicolumn{4}{|c|}{ Decomposers } & & & & \\
\hline & $\mathbf{J}$ & $\mathbf{C}$ & $\mathbf{N}$ & Mean & \multicolumn{4}{|c|}{ 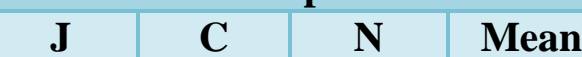 } \\
\hline FYM & 19.80 & 18.44 & 13.97 & 17.41 & 34.83 & 32.68 & 25.62 & 31.04 \\
\hline VC & 21.45 & 19.75 & 17.64 & 19.61 & 37.43 & 34.75 & 31.42 & 34.53 \\
\hline PM & 20.53 & 19.74 & 15.35 & 18.54 & 35.98 & 34.73 & 27.80 & 32.84 \\
\hline SM & 20.05 & 19.33 & 14.51 & 17.97 & 35.22 & 34.09 & 26.48 & 31.93 \\
\hline \multirow[t]{2}{*}{ Mean } & 20.46 & 19.32 & 15.37 & & 34.83 & 32.68 & 25.62 & 31.04 \\
\hline & \multicolumn{2}{|c|}{ S.Em \pm} & \multicolumn{2}{|c|}{$\mathrm{CD}(\mathbf{P}=\mathbf{0 . 0 5})$} & S.I & $n \pm$ & CD (1) & $=\mathbf{0 . 0 5})$ \\
\hline $\mathbf{M}$ & & & & & & & & 70 \\
\hline D & & & & & & & & \\
\hline M x D & & & & & & & & \\
\hline
\end{tabular}

CD at $5 \%$ NS - Non-Significant DAT- Days After Transplanting M - Manures RDF: 125:75:63 kg N: $\mathrm{P}_{2} \mathrm{O}_{5}: \mathrm{K}_{2} \mathrm{O}$ ha ${ }^{-1}$ for $\mathrm{N}$ equivalent FYM application $\quad$ D - Decomposers FYM - Farm yard manure VC - Vermicompost $\quad$ PM - Poultry manure $\quad$ SM - Sheep manure J-Jeevamrutha $\quad$ C- Microbial Consortia $\quad$ N-Decomposer from NCOF 
Table.4 Enzyme activity of soil at active flowering stage of chilli as influenced by application of organic manures, jeevamrutha and decomposers during kharif 2017

\begin{tabular}{|c|c|c|c|c|c|c|c|c|}
\hline \multirow[t]{4}{*}{ Manures } & \multicolumn{8}{|c|}{ Enzyme activities } \\
\hline & \multirow{2}{*}{\multicolumn{4}{|c|}{$\begin{array}{c}\left.\begin{array}{c}\text { Dehydrogenase activity } \\
\left(\mu \mathrm{g} \text { TPF formed } \mathrm{g}^{-1} \text { of soil day }\right.\end{array}{ }^{-1}\right) \\
\text { Decomposers }\end{array}$}} & \multirow{2}{*}{\multicolumn{4}{|c|}{$\begin{array}{c}\text { Acid phosphatase activity } \\
\left(\mu \mathrm{g} \text { PNP formed } \mathrm{g}^{-1} \text { of soil hour }{ }^{-1}\right) \\
\text { Decomposers }\end{array}$}} \\
\hline & & & & & & & & \\
\hline & $\mathbf{J}$ & $\mathbf{C}$ & $\mathbf{N}$ & Mean & $\mathbf{J}$ & $\mathbf{C}$ & $\mathbf{N}$ & Mean \\
\hline FYM & 54.19 & 50.63 & 38.95 & 47.92 & 31.67 & 29.64 & 22.99 & 28.10 \\
\hline VC & 58.50 & 54.06 & 48.55 & 53.70 & 34.12 & 31.55 & 28.37 & 31.35 \\
\hline $\mathbf{P M}$ & 56.09 & 54.03 & 42.55 & 50.89 & 32.73 & 31.54 & 24.91 & 29.72 \\
\hline SM & 54.84 & 52.97 & 40.37 & 49.39 & 32.00 & 30.92 & 23.64 & 28.86 \\
\hline \multirow[t]{2}{*}{ Mean } & 55.91 & 52.92 & 42.60 & & 32.63 & 30.91 & 24.98 & \\
\hline & \multicolumn{2}{|c|}{ S.Em \pm} & \multicolumn{2}{|c|}{$\mathrm{CD}(\mathrm{P}=0.05)$} & \multicolumn{2}{|c|}{ S.Em \pm} & \multicolumn{2}{|c|}{$\mathrm{CD}(P=0.05)$} \\
\hline $\mathbf{M}$ & \multicolumn{2}{|c|}{1.338} & \multicolumn{2}{|c|}{3.924} & \multicolumn{2}{|c|}{0.782} & \multicolumn{2}{|c|}{2.293} \\
\hline D & \multicolumn{2}{|c|}{1.159} & \multicolumn{2}{|c|}{3.398} & \multicolumn{2}{|c|}{0.677} & \multicolumn{2}{|c|}{1.986} \\
\hline M x D & \multicolumn{2}{|c|}{2.317} & \multicolumn{2}{|c|}{ NS } & \multicolumn{2}{|c|}{1.354} & \multicolumn{2}{|c|}{ NS } \\
\hline \multirow[t]{4}{*}{ Manures } & \multicolumn{8}{|c|}{ Enzyme activities } \\
\hline & \multicolumn{4}{|c|}{$\begin{array}{l}\text { Alkaline phosphatase activity } \\
\left(\mu \mathrm{g} \text { PNP formed } \mathrm{g}^{-1} \text { of soil hour }{ }^{-1}\right)\end{array}$} & \multicolumn{4}{|c|}{$\begin{array}{c}\text { Urease activity } \\
\left(\mu \mathrm{g} \mathrm{NH}_{4}-\mathrm{N} \text { formed } \mathrm{g}^{-1} \text { of soil hour }{ }^{-1}\right)\end{array}$} \\
\hline & \multicolumn{4}{|c|}{ Decomposers } & \multicolumn{4}{|c|}{ Decomposers } \\
\hline & $\mathbf{J}$ & $\mathbf{C}$ & $\mathbf{N}$ & Mean & $\mathbf{J}$ & $\mathbf{C}$ & $\mathbf{N}$ & Mean \\
\hline FYM & 21.89 & 20.48 & 15.89 & 19.42 & 6.02 & 5.63 & 4.33 & 5.32 \\
\hline $\mathbf{V C}$ & 23.58 & 21.81 & 19.61 & 21.66 & 6.50 & 6.01 & 5.39 & 5.97 \\
\hline $\mathbf{P M}$ & 22.62 & 21.79 & 17.21 & 20.54 & 6.23 & 6.00 & 4.73 & 5.65 \\
\hline SM & 22.12 & 21.37 & 16.34 & 19.94 & 6.09 & 5.89 & 4.49 & 5.49 \\
\hline \multirow[t]{2}{*}{ Mean } & 22.55 & 21.36 & 17.26 & & 6.21 & 5.88 & 4.73 & \\
\hline & \multicolumn{2}{|c|}{ S.Em \pm} & \multicolumn{2}{|c|}{$\mathrm{CD}(\mathrm{P}=0.05)$} & \multicolumn{2}{|c|}{ S.Em \pm} & \multicolumn{2}{|c|}{$\mathrm{CD}(\mathrm{P}=0.05)$} \\
\hline $\mathbf{M}$ & & & & & & & & \\
\hline D & & & & & & & & \\
\hline $\mathbf{M} \times \mathbf{D}$ & & & & & & & & \\
\hline
\end{tabular}

CD at $5 \%$ NS - Non-Significant DAT- Days After Transplanting $\quad$ M - Manures RDF: 125:75:63 kg N: $\mathrm{P}_{2} \mathrm{O}_{5}: \mathrm{K}_{2} \mathrm{O}$ ha ${ }^{-1}$ for $\mathrm{N}$ equivalent FYM application $\quad$ D - Decomposers FYM - Farm yard manure VC-Vermicompost $\quad$ PM - Poultry manure $\quad$ SM - Sheep manure $\mathbf{J}$ - Jeevamrutha $\quad \mathbf{C}$ - Microbial Consortia $\quad \mathbf{N}$ - Decomposer from NCOF 
Table.5 Enzyme activity of soil at active flowering stage of chilli as influenced by application of organic manures, jeevamrutha and decomposers during kharif 2018

\begin{tabular}{|c|c|c|c|c|c|c|c|c|}
\hline \multirow[t]{4}{*}{ Manures } & \multicolumn{8}{|c|}{ Enzyme activities } \\
\hline & \multirow{2}{*}{\multicolumn{4}{|c|}{$\begin{array}{c}\text { Dehydrogenase activity } \\
\left(\mu \mathrm{g} \text { TPF formed } \mathrm{g}^{-1} \text { of soil day }{ }^{-1}\right) \\
\text { Decomposers }\end{array}$}} & \multirow{2}{*}{\multicolumn{4}{|c|}{$\begin{array}{c}\begin{array}{c}\text { Acid phosphatase activity } \\
\left(\mu \mathrm{g} \text { PNP formed } \mathrm{g}^{-1} \text { of soil hour }\right.\end{array} \\
\text { Decomposers }\end{array}$}} \\
\hline & & & & & & & & \\
\hline & $\mathbf{J}$ & $\mathbf{C}$ & $\mathbf{N}$ & Mean & $\mathbf{J}$ & C & $\mathbf{N}$ & Mean \\
\hline FYM & 57.38 & 53.43 & 40.49 & 50.43 & 34.72 & 32.45 & 25.01 & 30.73 \\
\hline VC & 62.15 & 57.23 & 51.12 & 56.83 & 37.47 & 34.60 & 31.03 & 34.37 \\
\hline $\mathbf{P M}$ & 59.48 & 57.19 & 44.48 & 53.72 & 35.91 & 34.58 & 27.16 & 32.55 \\
\hline SM & 58.09 & 56.02 & 42.05 & 52.05 & 35.10 & 33.89 & 25.74 & 31.58 \\
\hline \multirow[t]{2}{*}{ Mean } & 59.28 & 55.97 & 44.53 & & 35.80 & 33.88 & 27.24 & \\
\hline & \multicolumn{2}{|c|}{ S.Em \pm} & \multicolumn{2}{|c|}{$\mathrm{CD}(\mathrm{P}=0.05)$} & \multicolumn{2}{|c|}{ S.Em \pm} & \multicolumn{2}{|c|}{$\mathrm{CD}(\mathrm{P}=\mathbf{0 . 0 5})$} \\
\hline $\mathbf{M}$ & \multicolumn{2}{|c|}{1.466} & \multicolumn{2}{|c|}{4.298} & \multicolumn{2}{|c|}{0.889} & \multicolumn{2}{|c|}{2.607} \\
\hline D & \multicolumn{2}{|c|}{1.269} & \multicolumn{2}{|c|}{3.722} & \multicolumn{2}{|c|}{0.770} & \multicolumn{2}{|c|}{2.258} \\
\hline M x D & \multicolumn{2}{|c|}{2.538} & \multicolumn{2}{|c|}{ NS } & \multicolumn{2}{|c|}{1.540} & \multicolumn{2}{|c|}{ NS } \\
\hline \multirow[t]{4}{*}{ Manures } & \multicolumn{8}{|c|}{ Enzyme activity } \\
\hline & \multicolumn{4}{|c|}{$\begin{array}{l}\text { Alkaline phosphatase activity } \\
\left(\mu \mathrm{g} \text { PNP formed } \mathrm{g}^{-1} \text { of soil hour }{ }^{-1}\right)\end{array}$} & \multicolumn{4}{|c|}{$\begin{array}{c}\text { Urease activity } \\
\left(\mu \mathrm{g} \mathrm{NH}_{4}-\mathrm{N} \text { formed } \mathrm{g}^{-1} \text { of soil hour }{ }^{-1}\right)\end{array}$} \\
\hline & \multicolumn{4}{|c|}{ Decomposers } & \multicolumn{4}{|c|}{ Decomposers } \\
\hline & $\mathbf{J}$ & $\mathbf{C}$ & $\mathbf{N}$ & Mean & $\mathbf{J}$ & $\mathbf{C}$ & $\mathbf{N}$ & Mean \\
\hline FYM & 24.64 & 23.23 & 18.64 & 22.17 & 6.98 & 6.50 & 4.93 & 6.13 \\
\hline VC & 26.33 & 24.56 & 22.36 & 24.42 & 7.56 & 6.96 & 6.22 & 6.91 \\
\hline PM & 25.37 & 24.54 & 19.96 & 23.29 & 7.24 & 6.96 & 5.41 & 6.53 \\
\hline SM & 24.87 & 24.12 & 19.09 & 22.69 & 7.07 & 6.81 & 5.12 & 6.33 \\
\hline \multirow[t]{2}{*}{ Mean } & 25.30 & 24.11 & 20.01 & & 7.21 & 6.81 & 5.42 & \\
\hline & \multicolumn{2}{|c|}{ S.Em \pm} & \multicolumn{2}{|c|}{$\mathrm{CD}(\mathrm{P}=0.05)$} & \multicolumn{2}{|c|}{ S.Em \pm} & CD (1 & $=0.05)$ \\
\hline $\mathbf{M}$ & 0.5 & & & & & & & \\
\hline D & 0.4 & & & 73 & & & & \\
\hline $\mathbf{M} \times \mathbf{D}$ & 0.9 & & & & & & & \\
\hline $\begin{array}{l}\text { at } 5 \% \\
\text { F: } 125: 75: 63 \\
\text { I - Farm yar } \\
\text { eevamrutha }\end{array}$ & $\begin{array}{l}-\mathrm{Non}-\mathrm{s} \\
\mathrm{g} \mathrm{N}: \mathrm{P}_{2} \mathrm{C} \\
\text { hanure }\end{array}$ & Microb & ompost & $\begin{array}{l}\mathbf{P M}-\mathrm{Pc} \\
\mathbf{N}-\mathrm{Dec}\end{array}$ & poser $\mathrm{f}$ & $\begin{array}{l}\text { M - } \\
\text { D - } \\
\text { SM } \\
\text { NCOF }\end{array}$ & $\begin{array}{l}\text { res } \\
\text { mpo } \\
\text { ep m }\end{array}$ & \\
\hline
\end{tabular}


Effect of different organic manures, jeevamrutha and decomposers on soil enzymatic activity

Dehydrogenase is an extra cellular enzyme in the soil and considered to play an important role in the initial stage of oxidation of soil organic matter by transferring hydrogen or electron from substrates to acceptors indicates the microbial activity in the soil. Measurement of dehydrogenase represents immediate metabolic activities of soil microorganism at the time of the test. Soil dehydrogenase activity is an oxidative degradation process i.e., dehydrogenation of organic matter by transferring hydrogen and electrons from substrate to acceptors. Dehydrogenase enzymes play a significant role in the biological oxidation of soil organic matter. Dehydrogenase activity thus serves as an indicator of the microbiological redox systems and may be considered a good measure of microbial oxidative activities in soils (Casida et al., 1964).

Phosphatase activity is essential for conversion of organic substrates containing phosphorus into inorganic form through hydrolysis in the soil phosphatase being an important enzyme in soil is an oxidoreductase which plays a key role in $\mathrm{P}$ cycle of the environment (Eivazi and Tabatabai, 1977). Urease activity is directly related to type of vegetation and quality of incorporated organic materials and with fluctuation in nutrient levels due to associated changes in population of urolytic microbes in the soil. Urease is a hydrolase enzyme responsible for hydrolytic conversion of substrate, urea into $\mathrm{CO}_{2}$ and $\mathrm{NH}_{3}$. Urease enzyme assay is important in understanding mineralization of $\mathrm{N}$ element and its response to the application of organic fertilizers. Land use system, tillage and soil management systems particularly its relations up to the agriculture practices has led to extensive research investigation in the last 3 decades (Pancholy and Rice, 1973).
In the present investigation, application of vermicompost through $\mathrm{N}$ equivalent recorded significantly higher enzyme activity i.e., dehydrogenase activity (53.70 and $56.83 \mu \mathrm{g}$ TPF formed $\mathrm{g}^{-1}$ soil day ${ }^{-1}$ ), acid phosphatase activity ( 31.35 and $34.37 \mu \mathrm{g}$ PNP formed $\mathrm{g}^{-1}$ soil hour ${ }^{-1}$ ), alkaline phosphatase activity (21.66 and $24.42 \mu \mathrm{g}$ PNP formed $\mathrm{g}^{-1}$ soil hour ${ }^{1}$ ) and urease activity (5.97 and $6.91 \mathrm{~g} \mathrm{NH}_{4}-\mathrm{N}$ formed $\mathrm{g}^{-1}$ soil hour ${ }^{-1}$ ) as compared to FYM, poultry manure and sheep manure application during both the years (Table 4 and 5). These results are in conformity with finding of Clarholms (1993), Harrison (1982) and Tarafdar and Chhonkar (1978). Generally, soil enzyme activities are related to the soil organic matter content which might be improved due to inclusion of organic manure (Frankenberger and Dick, 1983). According to Ladd and Paul (1973) increase in dehydrogenase activity with increasing organic matter content and microbial population of the soil. Correlation with $\mathrm{C}: \mathrm{N}$ ratio of organic manures when $\mathrm{C}$ : $\mathrm{N}$ is wide i.e. higher oxidizable carbon leading to proliferation of microorganisms and higher activity i.e. why manure having lesser decomposition would have more microbial activity.

In the present study the value of acid and alkaline phosphatase activity in treatment consists of FYM were found significant. The results of the present study support the view of Manna and Ganguly (1998) who reported phosphatase activity can be improved by the addition of organic manures in combination with inorganic fertilizer. Therefore it can be inferred that significant increase in activities of dehydrogenases and phosphatases indicates that application of sources of organic manures such as enriched vermicompost enhanced build-up of microbial biomass and also maintained higher enzymatic activities.

Application of jeevamrutha at $20001 \mathrm{ha}^{-1}$ recorded significantly higher microbial 
activity viz., dehydrogenase activity (55.91 and $59.28 \mu \mathrm{g}$ TPF formed $\mathrm{g}^{-1}$ soil day ${ }^{-1}$ ), acid phosphatase activity (32.63 and $35.80 \mu \mathrm{g}$ PNP formed $\mathrm{g}^{-1}$ soil hour ${ }^{-1}$ ), alkaline phosphatase activity (22.25 and $25.30 \mu \mathrm{g}$ PNP formed $\mathrm{g}^{-1}$ soil hour ${ }^{-1}$ ) and urease activity (6.21 and 7.21 $\mu \mathrm{g} \mathrm{NH} \mathrm{NH}_{4} \mathrm{~N}$ formed $\mathrm{g}^{-1}$ soil hour ${ }^{-1}$ ) as compared to decomoser application during both the seasons, respectively. This might be due to quick buildupof soil microflora and fauna due to the application of jeevamruthawhich has consequently increased the enzymatic activity and helped in mineralization, solubilizationof native and applied nutrients and making them available in the soil for plant uptake.This can be attributed to increased availability of nutrients like NPK and micronutrients due to enzymatic activity in soil viz., urease, dehydrogenase, phosphatase mediated by soil microorganisms. Such increased plant nutrient availability in soil due to enzyme activity by microorganisms was also earlier reported by Boomiraj and Christopar (2007). Among the different treatment combinations, application of vermicompost and jeevamrutha at 20001 $\mathrm{ha}^{-1}$ recorded higher microbial activity viz., dehydrogenase activity (58.50 and $62.15 \mu \mathrm{g}$ TPF formed $\mathrm{g}^{-1}$ of soil day $\left.^{-1}\right)$, acid phosphatase activity (34.12 and 37.47 $\mu \mathrm{g}$ PNP formed $\mathrm{g}^{-1}$ of soil hour ${ }^{-1}$ ), alkaline phosphatase activity (23.58 and $26.33 \mu \mathrm{g}$ PNP formed $\mathrm{g}^{-1}$ of soil hour ${ }^{-1}$ ) and urease activity (6.50 and $7.56 \mu \mathrm{g} \mathrm{NH}_{4}-\mathrm{N}$ formed $\mathrm{g}^{-1}$ of soil hour ${ }^{-1}$ ) as compared to other treatment combinations. The urease, phosphatase and dehydrogenase activities were higher in wheat crop grown well with the application with recommended dose of $\mathrm{N}$ through vermicompost. Thus the results of the present study are in conformity with the Meena et al., (2013) who reported soil enzymes and microbial populations (bacteria, fungi and actinomycetes) were higher due to organic manure application, but their levels and activities were not reflected in wheat crop under alluvial soils.

\section{References}

Anonymous, 2018, Food and Agriculture Organization of the United Nations. FAOSTAT database.http://www.fao.org.

BasavarajKumbar and Devakumar, N., 2017, Yield and yield attributes of organic frenchbean (Phaseolus vulgaris L.) as influenced by farm yard manure and liquid manures. Sci. Conference "Innov. Res. Organic Agric."19 $9^{\text {th }}$ Organic World Congress, New Delhi, India. pp. 489-492.

Bhattacharyya and Jha, 2012, Plant growthpromoting rhizobacteria (PGPR): emergence in agriculture. World $J$. Microbiol.Biotech.,28: 1327-1350.

Boomiraj, K. and Christopher, L. A., 2007, Impact of organic and inorganic sources of nutrients, panchagavya and botanicals spray on the soil microbial population and enzyme activity in bhendi (Abelmoschus esculentus L. Monech). J. Agri. Environ., 5: 257-261.

Boomiraj, K., 2003, Evaluation of organic sources of nutrients, Panchagavya and botanicals spray on bhendi (Abelmoschus esculentus Moench). M.Sc. (Agri.) thesis, Tamil Nadu Agric. University, Coimbatore.

Boraiah, B, Devakumar, N., Palanna, K. B. and Shubha, S., 2017a, Growth and yield of organic capsicum (Capsicum annuum L. var. grossum) as influenced by different sources, levels of organic manures and panchagavya application. Sci. Conference "Innov. Res. Organic Agric." $19^{\text {th }}$ Organic World Congress, New Delhi, India. pp. 451-454.

Casida, L. E., Klen, D. A. and Santoro, J., 1964, Soil dehydrogenase activity.Soil Sci.,98: 371-376

Clarholm,M., 1993, Microbial biomass P, labile P, and acid phosphatase activity in the humus layer of a spruce forest, after repeated additions of fertilizers. Bio.Ferti. Soils, 16 (4): 287-292.

Devakumar, N., Rao, G. G. E., Shubha, S., Imrankhan, Nagaraj and Gowda, S. B., 2008, Activities of Organic Farming Research Centre, Navile, Shimoga, Univ. Agric. Sci., Bengaluru, Karnataka, India.

Devakumar, N., Shubha, S., Gouder, S. B. and 
Rao, G. G. E., 2014, Microbial analytical studies of traditional organic preparations beejamrutha and jeevamrutha, Proc. Building Organic Bridges. 4th ISOFAR Scientific Conference, Istanbul, Turkey. pp. 639-644.

Eivazi, F. and Tabatabai, M. A., 1977, Phosphatases in soils.Soil Biol. Biochem., 9: 167-172.

Frankenberger, J. and Dick, W., 1983, Relationships between enzyme activities and microbial growth and activity indices in soil.Soil Sci. Soc. American J.,47: 945951.

Gomez, K. A. and Gomez, A. A. 1984, Statistical procedures agricultural research, an international rice research institute book, A Willey Inter Science Publication, John Willey and Sons, New York.

Harrison, P. G., 1982, Control of microbial growth and of amphipod grazing by water-soluble compounds from leaves of Zostera manna. Mar. Biol., 67: 225-230.

Kiran, 2014, Response of chickpea (CicerarietinumL.) to organic sources of nutrition under rainfed condition.M.Sc. Thesis, Univ. Agric. Sci., Raichur, Karnataka, India.

Kulvinder Kaur, Kapoor, K. K. and Gupta, A. P., 2005, Impact of organic manures with or without mineral fertilizers on soil chemical and biological properties under tropical conditions. J. Plant Nutr. Soil. Sci., 168 (1-3): 117-122.

Ladd, N. and Paul, E. A., 1973, Changes in enzymic activity and distribution of acidsoluble, amino acid nitrogen in soil during nitrogen immobilization and mineralization. Soil boil.,5: 825-840.

Latha, B., Devakumar, N., Ramesh Kumar, C. and Lavanya, G., 2016, Microbial diversity in organic conversion fields.Nat. Conference on Sustainable and Self Sufficient Production of Pulses through an Integrated Approach. University of Agriculture Science, Bengaluru. pp. 97.

Lavanya, G., Devakumar, N., Latha, B. and Ramesh Kumar, C., 2016, Influence of jeevamrutha and panchagavya on beneficial soil microbial population in organic fieldbean.In: Nat. Conf. on Sust.
Self Sufficient Prodn.of Pulses through an Integrated Approach. Bengaluru.pp. 98.

Vanya, G., Devakumar, N., Latha, B. and Ramesh Kumar, C., 2016, Influence of jeevamrutha and panchagavya on beneficial soil microbial population in organic fieldbean.In: Nat. Conf. on Sust. Self Sufficient Prodn.of Pulses through an Integrated Approach. Bengaluru.pp. 98.

Madhukumar, V. and Sharanappa, 2015, Effect of organic nutrient sources on the productivity of chilli hybrids and soil fertility.Ann. Plant Soil Res., 17: 340-342.

Manna, M. C. and Ganguly, T. K., 2001, Influence of FYM and fertilizer $\mathrm{N}$ on soil micro biomass dynamics turn over and activity of enzymes in a TypicHaplustert under soybean-wheat fallow system. Indian $J$. Agric. Res., 35 (1): 48-51.

Meena, S., Gothwal, R. K., Saxena, J., Mohan, M. K. and Ghosh, P., 2013, Chitinase production by a newly isolated thermotolerantPaenibacillus sp. BISR047.Ann. Microbiol., 64: 787-797.

Mohammad, K. S. and Farzaneh, Y. S., 2019, Benefits of organic fertilizers spray on growth quality of chilli pepper seedlings under cool temperature. J. Plant Nutri.,42 (6): 650-656.

Mohan Singh, 2003, Organic farming prospects in Indian agriculture, Souvenir of $68^{\text {th }}$ Annual Convention of India society Soil Science, CSAUT, Kanpur. pp. 52-60.

Natarajan, K., 2002, Panchagavya - A Manual, Mother India Press, Mapusa, Goa, India, pp.33.

Naveena, B. M., 2017, Organic nutrient management in finger millet (Eleusinecoracana L.).M. Sc. (Agri.) Thesis (Unpub.), Univ. Agric. Sci., Bengaluru.

Nileema Gore and Sreenivasa, M. N., 2011, Influence of liquid organic manures on growth, nutrient content and yield of tomato (Lycopersiconesculentum Mill.) in the sterilized soil. Karnataka J. Agric. Sci.,24 (2): 153-157.

Pancholy, S. K. and Rice, E. L., 1973, Soil enzymes in relation to old field succession: Amylase, invertase, cellulose, dehydrogenase and urease. Soil Sci. Soc. 
American Proc.,37: 47-50

Patel, M. M., Patel, K. M., Patel, D. M. and Desai, A. I., 2014, Effect of panchagavya on growth, nutrient uptake, microbial count and yield of cowpea (Vigna unguiculata).Green farming, 5 (4): 572576.

Patel, V. K., 2017, An economic analysis of production and marketing of chilli (Capsicum annuum L.) in Raigarh district of Chhattisgarh. M.Sc. thesis submitted to the Department of Agricultural Economics, College of Agriculture, Raipur, India.

Ramprasad, V., Srikanthamurthy, H. S., NingappaKakol, Shivakumar, Nagaraju, B., Ningaraju, Shashidhara, Doddappa, Vijay, A. R., Shivanna, M. Obanna, N. Pandu, A. C., Rama Satish, Sandhya, M. and Veena, P., 2009, Sustainable Agricultural Practices. Green Foundation, Bangalore, India. pp. 18-22.

RekhaGonal, 2017, Productivity and quality of baby corn and soil health as influenced by organic nutrient management. M.Sc. (Agri.) Thesis Univ. Agric. Sci. Bengaluru.

ReshmaSutar, Sujith, G. M. and Devakumar, N., 2018, Growth and yield of cowpea [Vignaunguiculata (L.)Walp] as influenced by jeevamrutha and panchagavya application. Int. J. Curr. Microbio.Applant Sci., 41 (1): 79-84.

Siddappa, 2015, Use of jeevamrutha and farmyard manure on growth and yield of fieldbean (Dolichos lablab L.)M. Sc. (Agri.) Thesis, Univ. Agric. Sci., Bengaluru.

Siddappa, Murali, K., Devakumar, N. and
Ningannabiradar, 2017, Effect of farm yard manure (FYM) and jeevamrutha on yield attributes and yield of Fieldbean (Dolichos lablab L.). $19^{\text {th }}$ Organic World Congress, New Delhi, India.pp, 463-466.

Somasundaram, E., 2003, Evaluation of organic sources of nutrients and Panchagavya spray on the growth and productivity of maize sunflower-greengram system.Ph.D. Thesis, Tamil Nadu Agric. University. Coimbatore.

Sreenivasa, M. N., Nagaraj, M. Naik. andBhat, S. N., 2009, Beneficial traits of microbial isolates of organic liquid manures. First Asian PGPR Congress for sustainable agriculture, 21-24 june, ANGRAU, Hyderabad.

Tarafdar, J. C. and Chhonkar, P. K., 1978, Status of phosphatases in the root soil interface of leguminous and non- leguminous crops. Boil. Ferti. Soil,3: 199-204.

Tharmaraj, K., Ganesh, P., Suresh, R., Anandan, and Kolanjinathan, 2011, A critical review on panchagavya - a boon plant, growth.Int. J. Pharmaceutical Bio.,2 (6): 1611-1614.

Vishwajith, Devkumar, N., Murali, K., Sujith, G. M., Brahma Prakash, G. P. and Gowda, R. C., 2019, Organic nutrient management in okra. Ph.D. (Agri.) Thesis, Univ. Agric. Sci., Bengaluru.

Yadav, B. K. and Lourduraj, C. A., 2006, Effect of organic manures and Panchagavyaspray on yield attributes, yield and economics of rice (Oryza sativa L.) quality. Crop Res., 32 (1): $1-5$.

\section{How to cite this article:}

Karale Gangadhar, N. Devakumar, Vishwajith and Lavanya, G. 2020. Influence of Different Sources of Organic Manures and Decomposers on Enzymatic Activity and Microbial Dynamics of Rhizosphere Soil of Chilli (Capsicum annum L.). Int.J.Curr.Microbiol.App.Sci. 9(01): 542555. doi: https://doi.org/10.20546/ijcmas.2020.901.060 